\title{
PENERAPAN METODE KONTEKSTUAL TERHADAP KEMAMPUAN MENULIS PUISI SISWA
}

\author{
Sri Elanda Yunita ${ }^{1}$, Rustam Efendi Rasyid ${ }^{2}$, Muhammad Takdir ${ }^{3}$ \\ 1,2,3 Universitas Muhammadiyah Sidenreng Rappang \\ Jl. Angkatan 45 No 1A Lautang Salo Rappang, Pancarijang, Sidenreng Rappang \\ srielandayunita@gmail.com
}

\begin{abstract}
Abstrak: Penerapan Metode Kontekstual terhadap Kemampuan Menulis Puisi Siswa. Tujuan penelitian adalah untuk mengetahui efektivitas penerapan model pembelajaran kontekstual terhadap kemampuan menulis puisi siswa kelas VII SMP Negeri 2 Alla Kecamatan Baroko Kabupaten Enrekang. Jenis penelitian ini menggunakan jenis kuantitatif dengan tipe penelitian deskriptif. Desain yang digunakan dalam penelitian ini adalah desain eksperimen dengan menggunakan 2 jenis sampel yaitu kelas eksperimen dan kelas kontrol dari keseluruhan populasi sebanyak 4 kelas. Hasil penelitian menunjukkan bahwa metode pembelajaran tersebut tergolong belum cukup efektif dikarenakan beberapa faktor yang menyebabkan proses terganggu di masa pandemi covid-19 ini. Namun pada dasarnya, metode pembelajaran ini dapat digunakan secara berkelanjutan untuk dapat meningkatkan kemampuan menulis puisi siswa ataupun dipembelajaran kemampuan lainnya. Nilai t-hitung untuk variable kelas Eksperimen sebesar 99,888 dengan probabilitas (Sig.) 0,000, sedangkan untuk variable kelas Kontrol nilai t-hitungnya sebesar 69.534 (lebih rendah daripada t-hitung variable Kelas Eksperimen) dengan nilai probabilitas (Sig.) 0,000 $<0,05$. Rata-rata dari nilai perolehannya kelas eksperimen sebesar 83.65 sedangkan kelas kontrol hanya sejumlah 76.58. Namun, untuk indeks gain skor yang diperoleh Kelas Eksperimen (dengan model pembelajaran Kontekstual) hanya sebesar 42.2 atau apabila dipersentasekan sebesar $42.2 \%$ dan termasuk dalam kategori kurang efektif.
\end{abstract}

Kata kunci: metode kontekstual, pembelajaran, menulis puisi.

\begin{abstract}
Application of Contextual Methods on Students' Poetry Writing Ability. The purpose of the study was to determine the effectiveness of the application of the contextual learning model on the ability to write poetry in seventh grade students of SMP Negeri 2 Alla, Baroko District, Enrekang Regency. This type of research uses a quantitative type with a descriptive research type. The design used in this study is an experimental design using 2 types of samples, namely the experimental class and the control class from the entire population of 4 classes. The results showed that the learning method was not effective enough due to several factors that caused the process to be disrupted during this covid-19 pandemic. But basically, this learning method can be used on an ongoing basis to improve students' poetry writing skills or learn other skills. The t-count value for the Experiment class variable is 99,888 with a probability (Sig.) 0.000 , while for the Control class variable the t-count value is 69,534 (lower than the Experimental Class variable tcount) with a probability value (Sig.) $0,000<0,05$. The average score for the experimental class was 83,65 while the control class was only 76,58. However, for the gain index score obtained by the Experimental Class (with the Contextual learning model) is only 42,2 or if it is a percentage of $42,2 \%$ and is included in the less effective.
\end{abstract}

Keyword: contextual method, learning, writing poetry. 
Sastra adalah media koneksi atau media untuk berhubungan yang penting, sastra dapat menjadikan hubungan lebih baik. Kita dapat menyampaikan pesan dan kesan kita. Kita bisa menggambarkan buah pikiran, pendapat, anggapan untuk orang-orang sehingga mereka bisa mengerti pendapat kita. Dengan itu, kita menyampaikan isi hati, bisa saling mengerti buah pikiran dan anggapan bahkan kita dapat membuat dunia maya (hayalan) menggunakan alat yang cuman dipunyai oleh orang yaitu sastra. Adapun cara paling utama dalam berinteraksi memakai bahasa yaitu ketepatan bersastra. Pemakaian sastra yang tidak karuan menyusahkan orang lain untuk mengerti. Ketepatan dan kebenaran untuk bersastra itu membutuhkan imajinasi dan pemikiran yang maksimal untuk ilmu sastra. Selain itu, keteraturan sastra itu mengandalkan ketentuan sastra yang normal yang berlapis secara objektif memakai strategi keahlian yang benar. Kegiatan adalah segmen yang tak dapat dipisahkan dalam seluruh kegiatan belajar yang terjadi pada murid menuntut ilmu di bangku sekolah. Namun, dalam menghadapi tugas menulis banyak murid menganggapnya sebagai beban berat. Pendapat itu muncul karena pekerjaan mencatat menyita banyak tenaga, waktu dan perhatian yang sungguhsungguh.

Sehubungan aktivitas menulis, perlu dingat bahwa banyak keuntungan yang bisa didapat dari pelaksanaan tugas atau kegiatan tersebut. Bakat mencatat berkaitan pada tiga bakat lain melalui proses yang berbagai macam.Untuk memperoleh keahlian sastra, kita bisa melewati deretan yang beraturan, mula-mula di masa balita kita mepelajari mencerna bahasa kemudian berbicara, setelah itu belajar mengeja dan mencatat. Keahlian cuman bisa didapatkan dan ditanggulangi dengan cara praktek dan memaksimalkan latihan. Pengembangan kemampuan menulis melibatkan banyak jenis kompetensi dan keterampilan dalam menggunakan struktur-struktur linguistik, sosiolinguistik, dan wacana. Mencatat bisa dilihat seperti proses generatip, yaitu proses tanpa didasarkan pada rencana tertentu. Para penulis menggunakan bermacammacam tehnik menulis, dan dengan cara itu iya mendapatkan produk tulisan yang mudah diterima pembaca daripada tehniktehnik menulis lainnya. Guru dapat menghasilkan melalui proses memberikan pekerjaan mencatat dengan tujuan yang berbeda. Sejak puluhan tahun yang lalu usaha menaikan kualitas pembelajaran sudah dilaksanakan. Adapun usaha itu, adalah merubah dan memperbaiki metoda pengajaran. Beberapa metoda belajar yang telah digunakan seperti cara penggunaan kaidah bahasa, cara memahami, cara melafal kata, cara pengaplikasian bahasa, cara menentukan tema, cara berinteraksi, cara bertanya, cara berpartisipasi dengan teman dan metode kontekstual.

Model belajar pada pembelajaran kontekstual, yaitu: Mengaitkan (associate), Merasakan (Feel), Penerapan (Application), Kerja sama (Cooperation), Mengirim (Send), Kelebihan pembelajaran kontekstual menurut Mujahid (2005) adalah siswa lebih bisa menangkap pelajaran sebab materi dihubungkan pada keadaan lingkungan. Kekurangan dari metode tersebut yaitu (1) untuk menjalankan metode ini membutuhkan proses serta membutuhkan banyak waktu dalam pelaksanaanya, (2) pengajar condong membimbing karena pengajar bukanlah sebagai sumber informasi, dan (3) peran pengajar yaitu mengelolah murid dalam bentuk kelompok dan bekerjasama dalam menghasilkan pendidikan dan bakat yang akurat untuk anak didik. Menurut Sanjaya (2005) kelebihan metode kontekstual (1) menyumbangkan peluang untuk anak didik agar meningkatkan keinginan, meningkatkan bakat serta memperoleh informasi terbaru (2) menyampaikan peluang untuk anak didik dalam memperoleh maksud belajar melalui mengkolerasikan isi mata pelajaran dengan lingkungan siswa. Kelemahannya (1) pengajar dapat mengosongkan kesempatan yang maksimal untuk mencari informasi-informasi terbaru yang nantinya dapat berguna pada kegiatan belajar siswa sehingga membutuhkan tenaga dan pemikiran melelahkan dan boros waktu bagi guru, dan (2) pengajar pada kegiatan belajar akan membutuhkan kesempatan yang lumayan lama. Menurut Anisa (2013) kelebihan metode kontekstual yaitu, (1) belajar yang bermanfaat, maksudnya anak didik berusaha sendiri dalam melakukan kegiatan yang berkaitan 
dengan pelajarannya (2) belajar akan bermanfaat dan bisa mengembangkan rancangan pada anak didik sebab metode kontekstual mengajak murid memperoleh sendiri dan tidak menghafal (3) menumbuhkan kebenaran siswa menyampaikan anggapan mengenai bahan yang dipelajari, (4) meningkatkan keingin tahuan mengenai bahan pelajaran serta mengajukan pertanyaan pada guru, (5) meningkatkan keterampilan saat menyelesaikan permasalahan bersama dengan siswa yang lain, dan (6) anak didik bisa berkonsep mengenai kegitan belajar. Pembelajaran dengan menggunakan metode kontekstual/CTL, terdapat beberapa kriteria yaitu: Berdasarkan observasi awal yang dilakukan, kelas VII SMP Negeri 2 Alla Kecamatan Baroko Kabupaten Enrekang cukup mengalami kesulitan dalam pembelajaran Bahasa Indonesia khususnya dalam menulis puisi. Siswa merasa kurang memahami dalam menulis puisi. Siswa merasa cukup kesulitan ketika harus mencari kata-kata dengan idenya sendiri untuk mendeskripsikan gagasan atau objek puisi karena siswa hanya membayangkan objek puisi tersebut. Pada saat menulis puisi siswa belum bisa memilih kata dengan Pengertian pembelajaran kontekstual (contextual teaching and learning) yaitu baik dan sesuai. Selain itu, siswa juga belum memperhatikan penggunaan rima dalam menulis puisi. Kondisi tersebut karena beberapa faktor, di antaranya kurangnya latihan menulis puisi, keterbatasan waktu dalam pembelajaran menulis puisi, proses belajar mengajar yang kurang menarik dan menyenangkan, timbulnya perasaan bosan pada diri siswa yang mengakibatkan siswa ramai dan tidak memperhatikan penjelasan guru sehingga banyak siswa yang kurang memahami bagaimana menulis puisi yang baik dan benar. Menulis mempunyai peranan penting bagi manusia.Menulis adalah suatu cara berkomunikasi seperti halnya berbicara.Namun, dalam praktiknya pemakaian sastra pada mengarang tidak mirip kegiatan berbicara.Sebab sastra dipakai dengan fungsional yakni penggunaan sastra untuk alat komunikasi dan pengiriman. Aktivitas menulis membutuhkan kekuatan dan kebolehan saat pemakaian bahasa beraktifitas melalui cara-cara yang teratur, tanggapan dengan tertib dan menyampaikan dengan tertulis. Menurut Tirto Suwando, (2012:33) mengemukakan bahwa mengarang berfungsi untuk menghidupkan daya cipta. Sebab mengarang membutuhkan beberapa kapasitas pembantu dan dalam memperolehnya dibutuhkan ketekunan, kemauan keinginan, bahkan giat menimba ilmu serta berlatih. Maka sebab itu, pantas apabila dikatakan bahwa menciptakan ilmu budaya menulis/mengarang memotivasi individu agar lebih aktif, kreatif serta berpengetahuan. Berhubungan pada sasaran menulis, Secara umum, puisi yaitu sebuah karya tulis yang bersumber pada isi hati seorang penulis. Karya tulis itu ditulis menurut isi hati penulis. Dengan pemakaian gaya bahasa yang didalamnya terdapat maksud irama, rima, lirik serta bait. Selanjutnya dikemukakan arti puisi berdasarkan pendapat berbagai ahli dan bermacam seluk beluk pada puisi. Menulis puisi merupakan penulisan kreatif secara subjektif yang memungkinkan adanya penafsiran yang berbeda. Adanya perbedaan tersebut masih ada toleransi terhadap berbagai aspek bahasa sepanjang itu mempunyai dampak estetis. Berbeda dengan penulisan ilmiah yang ada tuntutan bahasa harus formal dan baku, dan disikapi secara objektif, bukan subjektif. Hal itulah yang membedakan antara penilaian ragam bahasa ilmiah dan sastra (Nurgiyantoro, 2012: 486).

Pengertian pembelajaran kontekstual (contextual teaching and learning) yaitu proses mengajar yang menjembatangi pengajar untuk menghubungkan bahan pelajaran dengan keadaan lingkungan anak didik dan mengajak anak didik untuk menghubungkan ilmu yang dikuasainya dan diterapkan dalam ligkungan. Metode kontekstual dalam kegiatan belajar atau lebih dikenal dengan sebutan Contextual Teaching and Learning (CTL) adalah proses mengajar yang menjembatangi pengajar untuk menghubungkan bahan pelajaran dengan keadaan lingkungan anak didik dan mengajak anak didik untuk menghubungkan ilmu yang dikuasainya dan diterapkan dalam ligkungan. Metode kontekstual dalam 
kegiatan belajar atau lebih dikenal dengan sebutan Contextual Teaching and Learning (CTL) adalah proses belajar yang menolong pengajar dalam menghubungkan bahan pelajaran dengan keadaan dunia nyata anak murid dan bisa mendorong mereka mampu mengaitkan dengan ilmu yang didapat dan diterapkan dalam kehidupannya secara pribadi maupun dalam masyarakat (Sudirman,2004:220). Menurut Eleine B. Jhonson (2008) metode kontekstual yaitu suatu sistem yang menarik pikiran agar bisa membuat struktur untuk menghasilkan arti. Kondisi tersebut terjadi karena guru belum menggunakan pendekatan dan metode pembelajaran yang bervariasi sehingga menyebabkan siswa kurang tertarik dalam mengikuti pembelajaran.

Salah satu pendekatan pembelajaran yang cocok diterapkan pada mata pelajaran Bahasa Indonesia dan sesuai dengan tahap berpikir konkrit siswa adalah pendekatan kontekstual atau sering disebut Contextual Teaching and Learning (CTL). Dengan pendekatan tersebut siswa diharapkan lebih mudah mendapatkan gagasan dari apa yang siswa alami langsung. Pendekatan ini, merupakan konsep belajar yang menghubungkan antara pengetahuan yang dimiliki siswa dengan penerapan dalam kehidupan sehari-hari. Metode pembelajaran kontekstual ini,mengaitkan pembelajaran dengan lingkungan sekitar siswa sehingga belajar tidak hanya berlangsung di ruang kelas tapi bisa dimana saja di sekitar lingkungan siswa. Selain itu, pendekatan ini memberikan keleluasaan siswa untuk mengeksplorasi sendiri pemikirannya tentang pembelajaran.

\section{METODE PENELITIAN}

Penelitian ini menggunakan pendekatan kuantitatif yang merupakan suatu bentuk metode penelitian yang digunakan untuk meneliti pada populasi atau sampel, pengumpulan data menggunakan instrumen penelitian, analisis data yang bersifat kuantitatif dengan tujuan untuk menguji hipotesis yang telah ditetapkan dengan tipe penelitian deskriptif. Jenis penelitian ini digolongkan ke dalam penelitian eksperimen. Penelitian eksperimen dapat diartikan sebagai penelitian yang digunakan untuk mencari perbedaan perlakuan tertentu terhadap yang lain dalam kondisi yang terkendalikan (Sugiyono, 2012).

Untuk kebutuhan pengumpulan data dengan menggunakan instrument penelitian beserta dokumentasi yang digunakan untuk mendapatkan informasi atau data dari apa yang di teliti oleh peneliti yang dimana didapat berupa foto dari lokasi penelitian, tes hingga observasi. Teknik analisis data menggunakan uji normalitas, uji homogenitas hingga uji hipotesis menggunakan paired sample t-test dan uji normalitas atau $n$-Gain score. Desain yang digunakan dalam penelitian ini adalah desain eksperimen dengan menggunakan 2 jenis sampel yaitu kelas eksperimen dan kelas kontrol dari keseluruhan populasi sebanyak 4 kelas. Populasi adalah wilayah generalisasi yang terdiri atas objek atau subjek yang mempunyai kualitas dan karakteristik yang ditetapkan oleh peneliti untuk dipelajari dan kemudian ditarik kesimpulannya (Sudirman,2004).

\section{HASIL DAN PEMBAHASAN}

Menulis puisi merupakan ungkapan perasaan penulis yang diterjemahkan dalam susunan kata- kata dalam bentuk bait-bait berirama dan memiliki makna yang dalam. Dengan kata lain, puisi merupakan gambaran perasaan seorang. Agar ungkapan perasaan ini dapat dinikmati dan dipahami, siswa harus memiliki keterampilan dalam menulis puisi, seperti penguasaan terhadap diksi, rima, tipografi. Model pembelajaran kontekstual didasarkan pada filosofi bahwa siswa mampu menyerap pelajaran apabila mereka dapat menangkap makna dari materi dan tugas-tugas sekolah yang diterima, jika mereka bisa mengaitkan informasi baru dengan pengetahuan dan pengalaman yang sudah dimiliki sebelumnya (Johnson, 2007). Dari penjelasan tersebut, dapat digarisbawahi bahwa dalam model siswa berperan utama.

Kemudian dengan melibatkan atau menggabungkan beberapa metode atau strategi dalam proses pembelajarannya seperti inquiry, diskusi, dan masyarakat belajar, siswa mampu menggali atau 
menemukan ide-ide untuk menulis puisi dari pengalaman mereka sendiri tanpa adanya kesulitan karena dilibatkan langsung dengan kehidupan sehari-hari. Tahapan awal yang dilaksanakan pada penelitian ini adalah melakukan pengamatan dengan melakukan tes awal untuk mengetahui pengetahuan dasar siswa materi pembelajaran menulis puisi.Selanjutnya, dalam penelitian ini yang ingin mengukur sejauh mana efektivitas penggunaan metode pembelajaran kontekstual terhadap kemampuan menulis puisi siswa Kelas VII SMP Negeri 2 Alla Kecamatan Baroko Kabupaten Enrekang, diambil 2 (dua) Kelas yang akan dijadikan sebagai sampel dari keseluruhan populasi Siswa Kelas VII di sekolah tersebut untuk diberikan metode pembelajaran yang berbeda tentang menulis puisi. Kelas pertama yang mengunakan kelas eksperimen dengan menggunakan metode pembelajaran kontekstual sedangkan untuk kelas kedua yaitu kelas kontrol menggunakan pendekatan konvensional dalam proses belajar mengajaranya. Kedua kelas yang digunakan sebagai sampel pada penelitian ini yaitu kelas pertama (VII A) dengan jumlah siswa 26 orang disebut sebagai Kelas Eksperimen dengan menggunakan metode pembelajaran kontekstual, sedangkan kelas kedua (VII B) dengan jumlah siswa 26 orang disebut Kelas Kontrol yang menggunakan pendekatan konvensional. Berdasarkan hasil penelitian yang telah dilakukan terkait dengan efektivitas penggunaan metode pembelajaran kontekstual terhadap kemampuan menulis puisi siswa, maka hasil penelitian ini akan disajikan dalam bentuk penyajian data yang sesuai dengan hasil pengukuran yang telah dilakukan sebelumnya yang mencakup nilai perolehan siswa kedua kelas sampel dalam menulis puisi yang masing-masing berbeda metode pembelajarannya. Analisis deskriptif memberikan gambaran atau deskripsi suatu data yang dilihat dari nilai ratarata (mean), standar deviasi, varian, maksimum, minimum, sum hingga range dari masing-masing variabel (Ghozali, 2011). Variabel yang digunakan meliputi variable Kelas Eksperimen (VII A) dengan metode pembelajaran kontekstual dan Kelas Kontrol (VII B) dengan metode pembelajaran konvensional. Uji Normalitas adalah sebagai pengujian tentang kenormalan distribusi data. Penggunaan uji normalitas adalah karena pada analisis statistik parametric, asumsi yang harus dimiliki oleh data bahwa data tersebut terdistribusi secara normal. Data yang mempunyai distribusi normal berarti mempunyai sebaran yang normal pula. Untuk mengetahui apakah data yang kita miliki normal atau tidak, kita menggunakan uji statistik Kolmogorov-Smirnov (K-S). Jika nilai signifikansi atau probabilitas $<0,05$, maka data yang ada dinyatakan terdistribusi secara tidak normal. Sebaliknya apabila nilai signifikansi atau probabilitas $>0,05$, maka data dinyatakan terdistribusi secara normal.

Untuk menjawab rumusan masalah yang diajukan, maka uji hipotesis yang digunakan adalah dengan menggunakan uji paired sampel t-test dan uji independent samples t-test. Uji paired samples t- test dilakukan untuk mengetahui pengaruh dari metode pembelajaran kontekstual terhadap kemampuan menulis puisi siswa, sedangkan uji independent samples t-test dilakukan untuk mengetahui perbedaan dari pengaruh metode pembelajaran tersebut terhadap keterampilan menulis puisi siswa. Pengolahan data dilakukan dengan menggunakan statistik SPSS versi 22. Hipotesis statistiknya adalah sebagai berikut : Nul hipotesis (H0): Metode pembelajaran kontekstual tidak efektif terhadap keterampilan menulis puisi siswa Kelas VII SMP Negeri 2 Alla Kecamatan Baroko Kabupaten Enrekang. Alternatif hipotesis (Ha): Metode pembelajaran kontekstual efektif terhadap keterampilan menulis puisi siswa Kelas VII SMP Negeri 2 Alla Kecamatan Baroko Kabupaten Enrekang. Uji Normalitas Gain (N-gain) menurut Hake merupakan eksperimen yang dapat memberikan gambaran tentang peningkatan hasil belajar antara sebelum dan sesudah penerapan model tertentu (Sundayana, 67: 2016). Berdasarkan definisi tersebut dapat dilihat perbedaan skor keterampilan siswa, baik yang meningkat maupun yang menurun, sehingga tes ini 
merupakan metode yang tepat untuk diterapkan untuk mengetahui keefektifan. Berdasarkan analisis data hasil penelitian terkait keefektifan metode pembelajaran kontekstual terhadap keterampilan menulis puisi siswa, disimpulkan bahwa memang terdapat perbedaan yang signifikan antara kelas eksperimen (pendekatan pembelajaran kontekstual) dan kelas kontrol (metode pembelajaran). ) .normal)) bila dilihat dengan mata telanjang, keduanya mendapatkan derajat. Setiap siswa berbeda secara signifikan dari rata-rata poin yang dikumpulkan dalam dua kelas sampel. Namun, jika mengacu pada interpretasi efektivitas poin N-Gain (Hake, 2014). Keefektifan metode pembelajaran kontekstual kurang efektif hanya diperoleh persentase $42,2 \%$. Survei ini dilakukan untuk mencari jawaban atas gagasan yang diajukan yaitu: (H0) Metode pembelajaran kontekstual tidak efektif dalam keterampilan menulis siswa kelas VII di SMP Negeri 2 Alla Kecamatan Baroko Kabupaten Enrekang, (Ha) Metode pembelajaran kontekstual adalah VII SMP Negeri 2 Alla, Kecamatan Baroko, Kabupaten Enrekang.

Berdasarkan hasil analisis data yang dilakukan menggunakan program SPSS versi 22, diketahui bahwa kedua variable (Kelas Sampel) masing-masing berjumlah 26 sampel. Perolehan nilai minimum untuk Kelas Eksperimen adalah 75 sedangkan nilai maksimumnya ialah 90, berbeda dengan Kelas Kontrol dimana perolehan nilai minimumnya yaitu 70 dan nilai maksimumnya sebesar 86. Untuk Kelas Eksperimen, mean atau rata-rata dari skor perolehannya sebesar 83.65 dan untuk Kelas Kontrol rata-rata skor perolehannya sejumlah 76.58. Kemudian kedua kelas yang dijadkan sebagai sampel terdistribusi normal dan homogen. Dilihat dari nilai signifikansi atau propabilitas (sig.) menunjukkan angka 0.050 untuk uji normalitas dan nilai signifikansi (sig.) sebesar 0,079 untuk uji homogenitas. Karena signifikansi dari keduanya lebih besar dari 0,05 maka dapat disimpulkan bahwa variable dari kedua atau lebih kelompok data yang ada normal dan homogen. Hasil uji paired sampel t- test dan uji independent samples t- test yang dilakukan untuk mengetahui pengaruh dari metode pembelajaran kontekstual terhadap kemampuan menulis puisi siswa diperoleh hasil bahwa nilai t-hitung untuk variable kelas Eksperimen (VII A) dengan metode pembelajaran kontekstual sebesar 99,888 dengan probabilitas (Sig.) $0,000<0,05$. Sedangkan untuk variable kelas Kontrol (VII B) dengan metode pembelajaran konvensional nilai t-hitungnya sebesar 69.534 (lebih rendah daripada t-hitung variable Kelas Eksperimen) dengan nilai probabilitas (Sig.) 0,000 $<0,05$. Karena probabilitas (Sig.) dari kedua variable yaitu $0,000<0,05$, maka dinyatakan $\mathrm{H} 0$ ditolak. Artinya terdapat pengaruh yang signifikan dari metode pembelajaran kontekstual terhadap kemampuan menulis puisi siswa kelas VII.

Jadi, F-hitung diperkirakan memiliki varians sebesar 3,216 dengan probability pengujian dua arah (sign. 2-tailed) 0,000. Karena probabilitas uji dua arah (sign. 2tailed) adalah $0,000<0,05, \mathrm{H}_{0}$ juga ditolak dan $\mathrm{H}_{\mathrm{a}}$ diterima secara otomatis. Artinya terdapat perbedaan yang signifikan antara proses pembelajaran kontekstual di kelas eksperimen dan pembelajaran konvensional di kelas kontrol. Selanjutnya dari hasil pengumpulan data disimpulkan bahwa keterampilan menulis puisi siswa melalui metode pembelajaran kontekstual berubah dan berdampak lebih besar terhadap hasil belajar daripada metode pembelajaran konvensional.

Hal ini dibuktikan dengan peningkatan hasil belajar kemampuan menulis pusisi siswa dengan model pembelajaran kontesktual, mean/rata-ratanya lebih tinggi dibandingkan dengan metode pembelajaran konvensional.

Selanjutnya, untuk lebih memastikan hipotesis yang akan diterima ( $\mathrm{Ha}$ atau $\mathrm{HO})$ dimana sebelumnya telah di uji melalui analisis paired sampel t-test dan uji independent samples t-test dilakukan Uji Normalitas Gain (N-gain) untuk melihat selisih perbedaan skor perolehan siswa, baik dalam bentuk peningkatan maupun penurunan. Pengujian ini merupakan metode yang cocok untuk diterapkan dalam mengetahui efektivitas serta menentukan ada tidaknya perkembangan. Dari hasil pengujian tersebut diketahui bahwa mean / rata- rata indeks gain yang diperoleh Kelas Eksperimen (dengan model pembelajaran Kontekstual) sebesar 42.2 atau apabila 
dipersentasekan sebesar $42.2 \%$ dan termasuk dalam kategori kurang efektif, yang berarti bahwa penerapan metode pembelajaran kontekstual di kelas eksperimen belum dapat dikatakan efektif dikarenakan beberapa faktor yang dihadapi. Salah satunya dengan kondisi pandemi covid-19 dimana proses belajar mengajar berlangsung dengan tanpa kepastian.

Selanjutnya, efektivitas metode pembelajaran kontekstual terhadap kemampuan menulis puisi siswa, disimpulkan bahwa memang terdapat perbedaan signifikan antara kelas eksperimen (metode pembelajaran kontekstual) dengan kelas kontrol (metode pembelajaran konvensional) apabila ditinjau secara kasat mata, baik dari perolehan nilai setiap siswa yang cukup berbeda hingga rata-rata akumulasi nilai dari kedua kelas sampel. Namun apabila merujuk pada interpretas tafsiran efektivitas N-Gain Score (Hake, Sundayana 2014:151) efektivitas dari metode pembelajaran kontekstual terbilang kurang efektif dengan hanya memperoleh persentasi sebesar $42.2 \%$.

Beberapa Penelitian sebelumnya yang juga mengkaji terkait dengan pengujian kelas eksperimen dan kelas control terhadap peningkatan keterampilan menulis puisi siswa dengan menggunakan metode pembelajaran kontekstual, pada penelitian yang dilakukan oleh Amrin 2018 dengan judul Kemampuan Menulis Cerpen Dengan Menggunakan Metode Kontekstual yang cenderung menggunakan pengamatan yang hanya khusus mengenai pemakaian metode kontekstual untuk mengukur kemampuan menulis cerpen secara deskriptif, sedangkan penelitian penulis membahas tentang menulis puisi dengan metode kontekstual serta meneliti secara kuantitatif.

Kemudian penelitian yang dilakukan oleh Syawal tahun 2017 dengan judul Kemampuan Membuat Puisi Dengan Teknik Deskripsi Benda Konkret Peneliti ini memakai model deskripsi pada pembuatan puisi, penulis mendeskripsikan bagaimana murid pada saat membuat puisi dengan teknik deskriptif benda konkret serta pengamatan yang dibuat berbeda karena menjelaskan mengenai cara membuat puisi dengan teknik deskriptif benda konkret, sedangkan penulis memakai metode kontekstual dalam pembuatan puisi. Selanjutnya penelitian oleh Bahrul 2017 menggunakan model deskriptif pada membaca puisi. Peneliti mendeskripsikan untuk murid bagaimana membaca puisi serta pengamatan yang lakukan hanya menjelaskan bagaimana membaca puisi, sedangkan penulis yang menjelaskan bagaimana cara dalam membuat puisi dengan metode kontekstual.

\section{KESIMPULAN}

Berdasarkan hasil penelitian terkait dengan efektivitas metode pembelajaran kontekstual terhadap kemampuan menulis puisi siswa, maka dapat disimpulkan untuk saat ini metode pembelajaran tersebut tergolong belum cukup efektif apabila diadopsi dikarenakan beberapa faktor dan kendala yang menyebabkan proses belajar mengajar terganggu di masa pandemi covid19 ini. Namun pada dasarnya, metode pembelajaran ini dapat digunakan secara berkelanjutan dan dimanfaatkan untuk meningkatkan kemampuan menulis puisi siswa ataupun dipembelajaran kemampuan lainnya. Pengujian yang dilakukan dengan analisis data secara ilmiah untuk mengetahui pengaruh dari metode pembelajaran kontekstual ini terhadap kemampuan menulis puisi siswa, diperoleh hasil bahwa, metode pembelajaran kontekstual ini cukup berpengaruh terhadap kemampuan menulis puisi siswa. Untuk Kelas Eksperimen, mean atau rata-rata dari skor perolehannya sebesar 83.65 dan untuk Kelas Kontrol rata-rata skor perolehannya sejumlah 76.58. Dilihat dari nilai signifikansi atau propabilitas (sig.) menunjukkan angka 0.050 untuk uji normalitas dan nilai signifikansi (sig.) sebesar 0,079 untuk uji homogenitas.

Selanjutnya Hasil uji paired sampel t-test dan uji independent samples t-test diperoleh hasil bahwa nilai t-hitung untuk variable kelas Eksperimen (VII A) dengan metode pembelajaran kontekstual sebesar 99,888 dengan probabilitas (Sig.) 0,000 $<0,05$. Sedangkan untuk variable kelas Kontrol (VII B) dengan metode pembelajaran konvensional nilai t- 
hitungnya sebesar 69.534 (lebih rendah daripada t-hitung variable Kelas Eksperimen) dengan nilai probabilitas (Sig.) $0,000<0,05$. Karena probabilitas (Sig.) dari kedua variable yaitu $0,000<0,05$, maka dinyatakan $\mathrm{HO}$ ditolak. Kemudian nilai F-hitung untuk asumsi varians adalah 3,216 dengan probabilitas pengujian dua arah (Sig. 2-tailed) 0,000. Karena probabilitas pengujian dua arah (Sig. 2-tailed) $0,000<0,05$ maka H0 juga ditolak dan otomatis Ha diterima. Namun, dari hasil pengujian tersebut diketahui bahwa mean/

\section{DAFTAR PUSTAKA}

Abbas, Saleh. 2006. Pembelajaran Bahasa Indonesia Yang Efektif Disekolah Dasar. Jakarta: departemen pendidikan nasional dierktorat jendral pendidikan tinggi direktorat ketenagaan.

Ahmad Rofi'uddin dan Darmiyati Zuhdi. 2002. Pendidikan Bahasa dan Sastra Indonesia di Kelas Tinggi. Malang: Universitas Negeri Malang.

Blanchard. 2001. Metode Pembelajaran Kontekstual. Jakarta: Balai Pustaka.

Eleine B. Jhonson. 2008. Pembelajaran Kontekstual. Bandung: Angkasa.

Poerwadarminta. 1984. Kamus Umum Bahasa Indonesia Jakarta: Balai Pustaka.

Sanjaya.2005. Contextual Teaching and Learning (CTL). Penerbit: Ghalia Indonesia rata-rata indeks gain yang diperoleh Kelas Eksperimen (dengan model pembelajaran Kontekstual) sebesar 42.2 atau apabila dipersentasekan sebesar $42.2 \%$ dan termasuk dalam kategori kurang efektif, yang berarti bahwa penerapan metode pembelajaran kontekstual di kelas eksperimen belum dapat dikatakan efektif dikarenakan beberapa faktor yang dihadapi. Salah satunya dengan kondisi pandemi covid-19 dimana proses belajar mengajar berlangsung dengan tanpa kepastian.

Sanjaya, Wina. (2006). Strategi Pembelajaran Berorientasi Standar Proses Pendidikan. Jakarta: Kencana Prenada Media Group.

Sudirman. 2004. Interaksi dan Motivasi Belajar Mengajar. Jakarta : Raja Grafindo Perkasa.

Sugiyono. 2013. Metode Penelitian Kuantitatif, Kualitatif, dan Kombinasi (Mixed Methods) Edisi Keempat. Bandung : Alfabeta

Universitas Muhammadiyah Sidenreng Rappang. 2019. Panduan Penulisan Skripsi. Rappang Lembaga Penelitian dan Pengabdian Masyarakat.

Wardani, Raka Joni. 2001. Batasan terhadap Pendekatan. Bandung: UPI dan Rosdakarya. 